\title{
Konsep Sosial Karakter dalam Buku Egrang Pinjaman dan Bangga
}

\author{
Imam Sugiarto ${ }^{1}$, Tutuk Ningsih ${ }^{2}$ \\ ${ }^{12}$ Universitas Islam Negeri Prof. KH Saifuddin Zuhri \\ mammi.giarto@gmail.com, tutuk@iainpurwokerto.ac.id
}

\begin{abstract}
Childhood is a golden period to maximize personality formation. In the potential for social development of children's characters, the environment is very decisive in its formation, including what children read. The lack of social character possessed by children today presents its own challenges for parents. Researchers examine the story book Stilts Loans and Proud published by the Corruption Eradication Commission (KPK). This study is a qualitative descriptive study with the type of library research. This research results that the reading books published by the KPK contain integrity values, including; value of care and responsibility.
\end{abstract}

Keywords: Socio-Character, Child

\begin{abstract}
Abstrak: Usia anak merupakan masa emas untuk memaksimalkan pembentukan kepribadian. Dalam potensi perkembangan sosialkarakter anak, lingkungan adalah hal yang sangat menentukan dalam pembentukannya termasuk apa yang dibaca anak. Minimnya sosial-karakter yang dimiliki anak saat ini memberikan tantangan tersendiri bagi orang tua. Peneliti mengkaji buku cerita Egrang Pinjaman dan Bangga yang diterbitkan Komisi Pemberantasan Korupsi (KPK). Kajian ini adalah penelitian deskriptif kualitatif dengan jenis penelitian pustaka (library research). Penelitian ini menghasilkan bahwa buku bacaan yang diterbitkan KPK memuat nilai integritas di antaranya; nilai peduli dan tanggungjawab.
\end{abstract}

Kata Kunci: Sosial-karakter, Anak

\section{PENDAHULUAN}

AR-RIAYAH : Jurnal Pendidikan Dasar vol. 5, no. 1, 2021

IAIN Curup - Bengkulu l p ISSN 2580-362X; e ISSN 2580-3611

http://journal.iaincurup.ac.id/index.php/JPD

DOI: $10.29240 /$ jpd.v5i1. 2684 | p. 65-74 
Perkembangan sosial-karakter anak penting bagi orang tua. Anak-anak memiliki masa depan karena memiliki peran yang akan mengubah dunia. Perilaku dan sikap anak sejak dini akan tumbuh dan menjadi kepribadian saat dewasa nanti. Dalam pendidikan, masa anak adalah masa pembentukan watak dan kebiasaan sehingga pendidikan anak sangat diperhatikan dalam mengoptimalkan potensi perkembangan. Anak memiliki rasa keingintahuan yang tinggi, sehingga perilaku anak yang selalu bergerak dan mencoba mendapatkan hal yang diinginkannya adalah hal yang wajar. Interaksi yang sering dilakukan anak adalah meniru. Proses pengamatan anak adalah hal yang luar biasa dimiliki, karena pengamatan tersebut akan selalu anak uji cobakan.

Manusia sebagai makhluk sosial memberikan pengertian bahwa ia bagaimana pun adalah makhluk yang mandiri tetapi pada saat bersamaan akan membutuhkan yang lain. Kebijaksanaan manusia harus mengikuti kebijaksanaan orang lain. Di sinilah kebutuhan orang lain adalah hal yang penting untuk dirawat dan dipelihara. Orang yang lebih dulu hidup sebagai orang dewasa selalu lebih dulu memiliki peluang untuk mewariskan apa yang dimiliki baik secara material atau immaterial.

Warisan para orang dewasa inilah yang sebaiknya menjadi hal yang harus menjadi keteguhan dan prinsip dalam menjalani kehidupan. Anak-anak yang lahir kemudian ini kerap mendapatkan norma, nilai, dan keteguhan yang diperolehnya dari orang dewasa dan sedikit anak-anak yang cerdas yang berani mempertanyakannya. Kemampuan interaksi anak-anak inilah yang nantinya menentukan dan menjadi pola masyarakat. Perkembangan anak mencakup banyak hal yang memadukan beragam kepribadian melalui pengalamanpengalaman yang didapatkannya. Pengalaman anak-anak dalam mengenali, memahami dan mengkombinasikan apa yang menjadi prioritas dalam menentukan interaksinya inilah yang turut membentuk kepribadian anak-anak secara sosial-karakter.

Dalam potensi perkembangan sosial-karakter anak, lingkungan adalah hal yang sangat menentukan dalam pembentukannya. Hal ini sesuai dengan paham Behaviorisme yang menganggap bahwa lingkungan memiliki peran vital dalam pembentukan kepribadian seseorang. Jangkauan interaksi anak menjadi bahan yang akan diuji cobakan oleh anak. Lingkungan positif tentunya akan mendukung dan membantu potensi pertumbuhan yang diinginkan. Namun, jika hanya kekerasan, perilaku amoral, dan tindakan negatif lainnya yang selalu diperlihatkan pada anak. Tentunya dapat merusak perkembangan sosial-karakter anak.

Rasa ingin tahu anak yang tinggi membuat hal di sekitarnya menarik bagi anak. Anak akan mulai mengamati dan mencoba untuk bersentuhan dengannya. Bila hal itu adalah benda mati, anak akan mencoba memainkannya. Anak sangat 
menyukai keteraturan, meskipun begitu pola kebiasaan anak yang selalu melihat ketidakteraturan dapat merubah pola kesadaran anak. Pada perkembangan anak, sosial-karakter adalah bagian substansial. Lingkungan berperan dalam mengoptimalkan perkembangan tersebut. Peran orang tua yang tidak dapat meningkatkan pola sosial-karakter anak mengharuskan adanya resistensi terhadap lingkungan yang tidak mendukung.

Dongeng merupakan salah satu alternatif dalam membantu dan membentuk pola kesadaran anak. Di dalam dongeng terdapat potensi yang dapat mengembangkan dan meningkatkan kesadaran. Anak adalah pendengar yang baik, dengan begitu dongeng mendapat kesempatan untuk memberikan stimulus melalui cerita-cerita yang disisipkan di dalam dongeng. Di dalam dongeng terdapat kisah yang dapat menggali potensi kesadaran anak.

Dongeng atau kisah yang diceritakan anak menjadi salah satu alternatif dalam mengambil peran menumbuhkan dan mengajarkan sosial karakter pada anak. Semakin beragam anak memperoleh referensi tentang pengalaman interaksinya. Anak-anak akan mengkonsepsikan kenyataan kebenaran dan turut membangun perkembangan kepribadian diri anak. Dongeng atau kisah juga menjadi dimensi buatan yang memberikan iklim yang cukup baik untuk menyumbang landasan kenyataan sosial karakter pada anak.

Usia anak merupakan masa emas untuk memaksimalkan pembentukan kepribadian. Selama ini dongeng hanya berperan sebagai hiburan. Padahal dongeng memiliki potensi untuk menerjemahkan nilai-nilai moral pada anak melalui bahasa anak. Dengan begitu, pembahasan akan fokus konsep sosialkarakter dalam buku yang diterbitkan KPK. Peneliti membatasi kajian buku KPK pada judul diantaranya; Egrang Pinjaman dan Bangga.

\section{METODE PENELITIAN}

Kajian ini akan mengindentifikasi keilmiahan penelitian, sehingga peneliti akan menjelaskan rangkaian dengan prosedur ilmiah yang sistematis. Kajian ini adalah penelitian pustaka atau Library Research. Kajian pustaka memfokuskan pada pengumpulan data yang diambil dari buku, jurnal dan dokumen deskriptif yang mendukung kajian yang relevan. Adapun pendekatan yang digunakan adalah pendekatan fenomenologi. Pendekatan fenomenologi adalah pendekatan dalam mendeskripsikan pemaknaan umum dari sejumlah individu terhadap berbagai pengalaman hidup terkait dengan fenomena atau konsep. Pendekatan fenomenologi yang dikaji penulis memiliki perhatian pada persoalan yang muncul pada minimnya perhatian penguatan sosial karakter pada anak. Kajian pustaka ialah pengkajian dilakukan dengan objek yang diperoleh dari kepustakaan; misalnya seperti buku, jurnal ilmiah dan dokumen yang relevan.

Kajian ini memberikan penjelasan deskriptif yang memang digunakan pada penelitian kualitatif. Pendekatan penelitian ilmiah ini menggunakan data 
non angka. Yang berarti pengkaji memberikan penjelasan berupa dokuman manuskrip dan gagasan yang ada.

\section{A. Objek Penelitian}

Objek penelitian ini adalah Konsep Sosial Karakter dalam Buku yang Diterbitkan KPK (Komisi Pemberantasan Korupsi). KPK (Komisi Pemberantasan Korupsi) memiliki beragam program sosialiasi antikorupsi dan salah satunya meluaskan pada pemahaman-pemahaman yang ditujukan usia dini melalui buku cerita.

\section{B. Sumber Data}

Sumber primer sebagai sumber utama dalam penelitian ini adalah tulisan Muhamad Iqbal, dengan judul Nilai Pendidikan Antikorupsi dalam Buku-buku yang Diterbitkan KPK dan Implementasinya dalam Pembelajaran di Madrasah Ibtidaiyah. Pengkaji menggunakan tulisan tersebut sebagai sumber primer sebab kajian yang diteliti memiliki objek kajian yang sama yaitu buku KPK (Komisi Pemberantasan Korupsi). Pada tulisan Muhamad Iqbal memiliki ulasan tentang pemaknaan nilai-nilai yang tumbuh sejak dini dengan penggambaran melalui media cerita. Meskipun, ulasan masih terbatas pada pemaknaan umum. Namun, tulisan tersebut punya nilai tersendiri untuk memberikan penguatan pada kajian yang penulis teliti. Sehingga peneliti menjadi pengkaji selanjutnya untuk kajian pada persoalan yang sama.

Adapun tulisan yang menjadi sumber kajian kedua penulis peroleh dari jurnal atau penelitian terbaru yang memiliki kajian yang sama untuk mendapatkan penguatan pada pembahasan kajian sehingga data dan pengembangan yang dijelaskan tidak melebar dan keluar dari kajian.

\section{Metode Pengumpulan dan Analisis Data}

Kajian informasi merupakan upaya yang dicoba dengan bekerja mengelola, memilah- memilah, mengorganisasikan serta mensintesism data- data dalam risetDalam riset ini, tata cara analisisnya memakai tata cara analisis isi. Dari informasi serta data yang setelah terkumpul, berikutnya dicoba analisis informasi yang dicoba lewat 3 sesi. Dengan ketiga sesi ini didapatkan data yang cocok dengan topik riset, dan didapatkan pula informasi yang valid. Adapun tiga sesi yang dimaksud adalah sebagai berikut: Pertama, Reduksi data; Informasi ataupun dokumen yang telah terkumpul dianalisis, berikutnya hasil analisis ini menciptakan data- data ataupun data yang memanglah dibutuhkan dalam riset serta informasi yang tidak dibutuhkan. Informasi yang dibutuhkan dicoba pengelompokkan, sebaliknya informasi yang tidak cocok direduksi ataupun dihilangkan sebab tidak hendak mendukung hasil riset. Kedua, Klasifikasi data; Informasi ataupun data yang telah terkumpul diolah serta diklasifikasikan terlebih dulu cocok dengan konsep dasar teori serta riset ini. Klasifikasi ini berikutnya hendak menciptakan keseragaman informasi 
ataupun data cocok klasifikasinya, sehingga mempermudah dalam proses menganalisis. Ketiga, Sehabis diklasifikasi, data- data tersebut dianalisis cocok dengan konsep dasar teoretis serta metodologisnya. Hasil analisis inilah yang nantinya memberikan temuan- temuan riset yang berarti serta berikutnya diverifikasi dalam kesimpulan.

\section{HASIL DAN PEMBAHASAN}

Etika sosial dimaksud sebagai cara berpikir dalam menggerakkkan anggota badan dengan sikap tanggung jawab dan memiliki pertimbangan yang berasal dari hati. Menurut Prof. DR. Mar'at bahwa perubahan sikap ditentukan oleh faktor internal dan Faktor ekternal:

\section{A. Faktor Internal}

Faktor pertama yang ada dalam internal adalaha Posisi Sosial. Penerima informasi akan mempersepsikan komunikator sebagai obyek yang mempunyai arti. Hubungan antara komunikator dengan penerima informasi memiliki hubungan langsung dalam kaitannya posisi dengan masyarakat. Oleh karena itu posisi komunikator dapat mengubah sikap individu atau kelompok. Arti posisi ini dapat memiliki nilai keagamaan, pemerintah yang dapat diandalkan, kepandaian, kejujuran dan sebagainya. Posisi sosial yang dipersepsikan memiliki nilai tertentu seperti nilai moral dan hal ini akan dikaitkan dengan pengambilan keputusan bagi si penerima berita untuk mengubah sikap.

Kedua adalah Proses Belajar sosial. Penerima stimulus banyak dipengaruhi oleh kecenderungan. Tiap berita atau informasi akan senantiasa diolah nilai, disaring demi kepentingannya, jika hal ini menguntungkan bagi penerima berita, maka individu ini senantisa menerima dan mengolahnya melalui pengalaman dan berarti terdapat proses belajar.

\section{B. Faktor Eksternal}

Pertama, adalah Penguatan. Buat keberhasilan buat mengganti perilaku hingga komunikator butuh membagikan bonus stimulus( penguatan) supaya penerima kabar ingin mengganti perilaku. Perihal ini bisa dicoba dengan bermacam metode semacam dengan pemberian imbalan ataupun hukuman. Dengan metode demikian ini penerima kabar/ informsi hendak mempersepsikan selaku sesuatu makna yang berguna untuk dirinya serta terdapatnya sanksi apabila perihal ini tidak dicoba hingga dengan sendirinya penguatan ini wajib bisa dipahami serta diterima selaku perihal yang memiliki dampak langsung terhadap perilaku.

Kedua, Komunikasi Persuasif. Komunikasi persuasif ialah aktivitas penyampaian sesuatu data ataupun permasalahan kepada orang lain dengan metode menbujuk (aktivitas ini merupakan" influencing the emotional attitude of others" yang berarti pengaruhi perilaku emosi dari pihak lain. Ini umumnya dicoba pada mereka yang rasionya lumayan baik dan anggapan sosialnya 
selektif. Pendekatan dengan lewat komponen efeksi merupakan dengan metode emosional merupakan dengan metode ini diterima serta terdapat kepercayaan dalam dirinya atas kebenaran ilham ini hingga secara siuman hendak mencuat pergantian perilaku.

Ketiga, Harapan yang di inginkan. Dalam mencapai tujuan untuk memberikan respon yang diinginkan. Sikap persuasif dilakukan dengan dapat menangkap apa yang menjadi sesuatu yang diinginkan pada pihak lain. Dan memenuhi segala keinginannya dengan demikian orang yang menerima informasi akan terpengaruh dan dengan sendirinya seorang dapat berubah.

\section{Model Sosial Karakter dalam Buku yang diterbitkan KPK}

Dari beberapa judul buku terbitan Komisi Pemberantasan Korupsi. Penulis menemukan kutipan-kutipan yang mengandung nilai sosial-karakter. Berikut ini penulis paparkan kutipan untuk mewakili. Kutipan ini menurut $\mathrm{Iqbal}^{1}$ sebagai nilai peduli. Nilai peduli memiliki kedekatan pengertian pada sikap sosial. sosial-karakter menjelaskan pengertian yang lebih umum. Namun demikian, nilai peduli memberikan penjelasan sikap sosial yang ada. Berikut kutipannya;

"Sebenarnya, aku menyiapkan egrang ini untukmu, Bimo.

Sayang, sekarang patah. Bahaya jika dipakai lagi."

"Maafkan aku, Juma."

Kutipan di atas menunjukkan kepedulian. Kepedulian itu ditunjukkan dan diucapkan dengan perkataan "Sebenarnya, aku menyiapkan egrang ini untukmu, Bimo.". Tindakan tokoh Juma menunjukkan kepedulian kepada Bimo yang ingin belajar dan bermain Egrang. Di sinilah kesadaran dalam kewajiban diri memberikan sikap positif pada orang lain menunjukkan sikap mementingkan orang lain.

Pada judul buku yang lain buku terbitan Komisi Pemberantasan Korupsi. Penulis menemukan kutipan-kutipan yang memiliki makna nilai tanggungjawab (siap menanggung akibat dari perbuatan yang dilakukan, tidak buang badan). Seperti pada pengertian sebelumnya bahwa karakter memberikan pengertian melakukan keputusan penuh tanggungjawab. Karakter adalah sebuah keputusan yang tumbuh dan menjadi kebiasaan. Anak-anak yang tumbuh dengan karakter selalu memiliki kesiapan dan tanggung dalam menjalani kehidupan. Berikut ini penulis paparkan kutipan untuk mewakili:

\footnotetext{
1 Iqbal, Muhamad. Nilai Antikorupsi dalam Buku yang diterbitkan KPK dan Implementasinya dalam Pembelajaran Madrasah Ibtidaiyah. Skripsi, 2018.

${ }^{2}$ Kutipan ini diambil pada judul buku "Egrang Pinjaman" yang ditulis Yuniar Khairani. (Direktorat Pendidikan dan Pelayanan Masyarakat KPK: 2017)
} 
"TIDAK. Aku bukan pemimpin semacam itu. Aku di sini untuk mereka, dan mereka di sini untukku"”

Kutipan di atas mengandung nilai tanggungjawab. Nilai tanggungjawab tersebut ditunjukkan pada ucapan "TIDAK. Aku bukan pemimpin semacam itu. Aku di sini untuk mereka, dan mereka di sini untukku". Dalam cerita tersebut tokoh utama Ratu Lebah sebagai pemimpin menunjukkan karaktermya atas perannya sebagai pemimpin yang mengemban amanah. Di sinilah karakter menjadi hal yang penting untuk diperhatikan.

Ada beberapa kegiatan pendidikan antikorupsi pada anak tentang aktivitas sederhana yang melatih kepekaan sosialnya, di antaranya;

1. Membantu Pekerjaan Rumah. Perhatian orang tidak saja cukup ditunjukkan pada memberikan kebutuhan bagi anak. Kepribadian intrapersonal anak tentu harus diuji dengan bagaimana interaksi anak terhadap orang tuanya. Hal ini jugalah yang akan memberikan dampak pula kepada orang lain. Kepekaan sosial anak dapat dilihat dari bagaimana responnya di dalam keluarga. Orang tua tidak seharusnya memanjakan anak. Orang tua perlu melatih kepekaan sosial anak dengan memberikan tugas pekerjaan rumah. Rumah harus dimengerti anak sebagai bukan tempat milik sendiri. Rumah juga menjadi ruang berorganisasi dengan turut mengambil bagian pekerjaan rumah sejak dini. Orang tua dapat membagi pekerjaan dengan menyuruh anak menyapu setiap pagi atau di waktu lainnya sesuai keinginan anak. Orang tua dapat memberitahu anak halhal positif jika anak melakukannya. Ceritakan rumah yang sehat adalah rumah yangselalu disapu setiap hari. Dengan begitu, tidak lama kepekaan sosial anak dapat meningkat.

2. Membereskan Mainan. Orang tua dapat membebaskan anak bermain sesukanya. Tapi sesekali buatlah kesepakatan yang menguntungkan untuk kedua belah pihak. Mintalah selalu anak untuk membereskan mainannya selepas bermain. Hal ini akan memberikan pemahaman baik pada anak. Anak akan mengerti bahwa orang lain pun juga menginginkan keadaan baik dan terkendali.

3. Mendengarkan Orang Tua Bercerita. Tidak banyak orang tua menyadari bahwa interaksinya dengan anak memberikan efek positif. Anak-anak tentu perlu mendengar lebih banyak apa yang dikatakan oleh orang tuanya. Hal ini akan menjadi kebaikan bagi anak. Dengan memiliki aktivitas ini, domain afektif anak dapat terjaga.

Kegiatan yang relevan dengan ketertarikan anak menjadikan kebutuhan pandangan dan keyakinan yang diadaptasi melalui buku menjadi

${ }^{3}$ Kutipan ini diambil pada judul buku "Bangga" yang ditulis Sahlan. (Direktorat Pendidikan dan Pelayanan Masyarakat KPK: 2017) hlm. 22 
terpenuhi. Anak-anak akan belajar dan mengkombinasikan keyakinankeyakinannya sehingga memberikan cara berpikir yang tidak lama dapat membantu keputusan-keputusan pada anak. Keputusan-keputusan inilah yang lekat dari apa yang dibaca dan menjadi pengalaman anak sehingga ia menjadi bagian praktik dan kebiasaan di kehidupannya sehari-hari.

\section{KESIMPULAN}

Buku-buku menjadi hal penting untuk dikenalkan pada anak. Buku yang diterbitkan komisi pemberantasan korupsi memiliki konsep sosial-karakter yang dapat ditanamkan kepada anak. Memberikan pengajaran melalui buku memiliki nilai tersendiri. Anak-anak adalah peniru yang ulung. Pengalaman yang kaya di dalam buku dapat membantu membangun konsep sosial-karakter tersendiri pada anak. Pendidikan sosial-karakter yang dibangun melalui buku menjadi salah satu cara dalam menumbuhkan nilai positif pada anak. Buku yang dibaca menyesuaikan kondisi dan usia anak sehingga anak-anak memiliki kesenangan tersendiri dan memberikan perhatian penuh dalam mengkombinasikan keyakinan-keyakinan yang dimiliki anak.

\section{DAFTAR PUSTAKA}

Hendri, 2013. Pendidikan Karakter Berbasis Dongeng Simbiosa. Rekatama Media: Bandung

Isnaini, Muhammad . Internalisasi Nilai-Nilai Pendidikan Karakter Di Madrasah. Jurnal Al-Ta'lim, Jilid 1, Nomor 6 November 2013

Iqbal, Muhamad. 2018. Nilai Pendidikan Antikorupsi dalam Buku-buku yang Diterbitkan KPK dan Implementasinya dalam Pembelajaran di MI. Skripsi, IAIN Purwokerto

Khairani, Yuniar. 2017. Bangga. Direktorat Pendidikan dan Pelayanan Masyarakat Komisi Pemberantasan Korupsi Republik Indonesia: Jakarta.

Rafsel Tas'adi. Pentingnya Etika Dalam Pendidikan . Ta'dib, Volume 17, No. 2 (Desember 2014)

Sahlan. 2017. Bangga. Direktorat Pendidikan dan Pelayanan Masyarakat Komisi Pemberantasan Korupsi Republik Indonesia: Jakarta.

Sudarsana, I. K. (2017, October). Filosofis Asessorpenilaian Beban Kinerja Akademik Dosen Pendidikan Agama Hindu Pada Perguruan Tinggi. In Prosiding Seminar Pendidikan Agama 
Sudarsana, I. K. (2017, October). Pengembangan Pendidikan Berbasis Kearifan Lokal Untuk Mewujudkan Toleransi Antar Umat Beragama. In Prosiding Seminar Nasional Filsafat (Pp. 216-223).

Sudarsana, I. K. (2017, October). Peranan Orang Tua Dalam Penanaman Budi Pekerti Pada Anak. In Prosiding Seminar Nasional Anak Usia Dini (Semadi) 2 (Pp. 157-160).

Sudarsana, I. K. Peran Keluarga Dalam Membentuk Karakter Anak Usia Dini. Strategi Pembelajaran Anak Usia Dini Untuk Mewnjudkan Generasi Berkualitas.

Tatang Hidayat. Toto Suryana. Menggagas Pendidikan Islami: Meluruskan Paradigma Pendidikan Di Indonesia. JPII Volume 3, Nomor 1, Oktober 2018 